\title{
FACTORS INFLUENCING LAND REFORM BENEFICIARIES' WILLINGNESS TO PAY FOR EXTENSION SERVICES IN EASTERN CAPE AND KWAZULU-NATAL, SOUTH AFRICA
}

\author{
Loki, O. ${ }^{1}$, Mudhara, M. ${ }^{2}$, Pakela-Jezile, Y. ${ }^{3}$ and Mkhabela, T. S. ${ }^{4}$
}

Correspondence author: O. Loki. Email: lokio@arc.agric.za

\begin{abstract}
The study investigated the factors influencing land reform beneficiaries' willingness to pay for extension services. Furthermore, the study determined the extension services for which farmers were willing to pay, and the cost. The study was conducted in seven districts in the Eastern Cape and KwaZulu-Natal provinces. Research activities included a formal survey conducted on a sample of 111 farmers using simple random sampling. Data were collected using a structured questionnaire through interviews and using a semi-structured interview guide for focus group discussions. The study employed Chi-square and T-test analyses to determine the relationship between the socio-economic characteristics of the farmers and their willingness to pay for extension services. The main findings were that $64 \%$ of land reform beneficiaries were in favour of privatisation of extension services. Furthermore, $98 \%$ of these farmers said they were willing to pay for extension services and indicated the price and type of services preferred. From the results of the probit regression analysis, it was seen that farmers who were likely to pay are those who are younger, with larger land sizes, and who have access to extension services. The study concluded that farmers were in favour of privatisation and were willing to pay for extension services, as they felt this would improve their farm returns.
\end{abstract}

Keywords: Eastern Cape, Extension services, Land reform, Socio-economic characteristics, Willingness, KwaZulu-Natal

\section{INTRODUCTION}

The provision of agricultural services to farmers independent of government dates back to the 1980s in South Africa (Koch \& Terblanché, 2013). According to Liebenberg (2015), in the past three decades, the republic has seen an exodus of qualified extension personnel from government institutions to set up private consulting companies. This has resulted in the informal existence of a pluralistic extension system that offers services to various farmers across South Africa (Department of Agriculture, Forestry and Fisheries (DAFF), 2014). Such private or pluralistic forms of extension and advisory services are not yet popular or widespread across the country, particularly in the poorest areas (Rivera \& Alex, 2004; Zwane, 2016). This is due to a number of reasons such as limited extension radius (coverage), popularity, and most notably, they work on incentives; thus, they only provide extension support to farmers who are

\footnotetext{
${ }^{1} \mathrm{PhD}$ candidate, Agricultural Extension And Rural Resource Management, School of Agricultural Earth and Environmental Sciences, University of KwaZulu-Natal, Pietermaritzburg, South Africa, Email: lokio@arc.agric.za, ORCID nr.: 0000-0003-4187-3345

${ }^{2}$ Associate Professor, Agricultural Extension And Rural Resource Management, School of Agricultural Earth and Environmental Sciences, University of KwaZulu-Natal, Pietermaritzburg, South Africa, Email: Mudhara@ukzn.ac.za, ORCID nr.: 0000-0001-8739-0811

${ }^{3}$ Senior Manager, Agricultural Research Council, Pretoria, South Africa, Email: PakelaY@arc.agric.za

${ }^{4}$ Group executive, Agricultural Research Council, Pretoria, South Africa, Email: mkhabelat@arc.agric.za
} 
able to pay for services (Liebenberg, 2015). The emergence of these sectors has seen the government reduce its investment in agricultural extension services and this has led to many thinking that farmers will eventually transition from free-fee extension service to a fee-based service (Afful \& Lategan, 2014; Anderson \& Feder, 2004).

The evidence of success of the private extension services sector has managed to make noticeable contributions in a short space of time within the commercial farmers in South Africa and this has ignited a debate (Liebenberg, 2015). This debate centres on whether it would be feasible to privatise agricultural extension and advisory services in a country where the smallholder sector is the most dominant (Agholor, 2012). For most developing countries, this debate is difficult as there is enough evidence in the literature to suggest against and for privatisation (Rivera \& Alex, 2004). A number of studies across the globe have since shed light on the prospects of privatising extension services, but they have been inconclusive.

Some scholars (Labarthe \& Laurent, 2013; Oladele, 2008; Uddin \& Qijie, 2013; Zwane, 2016) are of the view that if extension services were privatised, there would a decrease in the fruitless expenditure incurred by the government sector, eradication of the top-down approach, and an increase in the efficiency of the extension service delivered. Further arguments are that if privatisation of extension services are carried out correctly, the returns would be immensely high; examples include the telecommunications and banking sectors (Rivera \& Alex, 2004). However, suggestions against privatisation are that it will be limited to a few and relatively financial stable farmers who can afford to pay for services (DAFF, 2014; Hellin, 2012). Another concern is the evidence from literature about the Technical-Entrepreneurial Assistance (ATE) programme of Chile, which in the later years of its existence hit the country's economy (Mwaura, Muwanika \& Okoboi, 2010; Rivera, 2001; Schwartz, 1994).

In searching for new delivery systems that will reduce wasteful government expenditure, increase extension efficiency, and cater for farmers' needs, information such as farmers' willingness to pay and which services they are willing to pay for become urgently important (Afful \& Lategan, 2014). Furthermore, South African experiences with fee-based services is a practice of commercial farmers' needs to be documented, analysed and disseminated for the better understanding and implementation of commercial prospects for smallholders (Liebenberg, 2015). However, such information is lacking or rather scarce in South Africa. The available literature is on international experiences and there is thus a need for further research on this concept (Gómez, Mueller \& Wheeler, 2016). It is against this background that this study was undertaken, so as to provide empirical evidence on smallholder farmers' willingness to pay for extension services. Furthermore, it aimed to probe which extension services farmers in South Africa are willing to pay for and at what price.

\section{THEORETICAL FRAMEWORK AND LITERATURE REVIEW}

The conceptual base for this paper lies on the idea to privatise agricultural extension services, introduce private companies to funding, and delivering extension services to smallholder farmers with the intention to improve their commercialisation prospects. Specifically, it examines the need for smallholder farming to change from free-fee extension to a fee-based advisory service and to a more results-oriented approach that is demand-driven with academic discipline yielding financial rewards to smallholder farmers. According to Ulimwengu and Sanyal (2011), willingness to pay is modeled as a sacrifice of current income in order to sustain or increase agricultural productivity in the future. Therefore, the expenditure function is used to estimate willingness to pay for improvement in the quality of a resource. The minimum 
expenditure level (e) required to achieve the initial utility level is given by the expenditure function as:

$e=e\left(p, E U_{0}, F_{0}\right)$

Where $\mathrm{p}$ is the vector of prices, $E U_{0}$, is the current expected utility level, and $F_{0}$ is the set of old agricultural services and farm characteristics. This means the amount of money a farmer spends in acquiring improved agricultural innovations is a function of prices, expected utility as well as agricultural services and farm characteristics. It follows that the willingness to pay in order to sustain current level of farm productivity is given by:

$W T P=e\left(p, E U_{0}, F_{0}\right)-e\left(p, E U_{0}, F_{1}\right)$

Where WTP is the amount at which a farmer feels indifferent between the expected marginal utility under the old set of technologies and the discounted expected marginal utility of the change in future incomes as a result of the new set of agricultural technologies; $F_{1}$ is the new set of agricultural services and farm characteristics. The private sector's willingness to commercialise their innovations can be analysed using willingness to accept (WTA) as proxy. WTA measures how much a respondent is willing to accept as compensation for a loss of a good or service. Contingent valuation tends to quantify the value consumers assign to products using a hypothetical purchasing situation in which they have to answer how much money they would be willing to pay (Wegary, 2013).

The study adopted the contingent valuation method (CVM). This technique fits squarely with the objectives and methodology followed in this paper, in that the respondents were asked to state their willingness to pay contingent on the provision of some hypothetical service (Njoko, 2014). For descriptive purposes, let us consider the changes to a consumer (farmer) resulting from a proposed new policy plan (e.g. privatisation of extension services). Let $W_{i}^{0}$ be the status quo of agricultural extension services level of welfare and $W_{i}^{1}$ the privatised extension services. In addition, let $W_{i}^{0} \equiv\left(y_{i}^{0}, P^{0}\right)$ and $W_{i}^{1} \equiv\left(y_{i}^{1}, P^{1}\right)$ represent the budgets that measure prices $(p)$ and incomes $(y)$ faced by consumer $i$ under the new policy plan. Therefore, the transition from status quo level to post-policy intervention level is simply the difference in the indirect utility given as:

$v^{0}\left(y_{i}^{0}, P^{0}\right)-v^{1}\left(y_{i}^{1}, P^{1}\right)$

Consumer $i$ will accept the change caused by privatising extension services if $v^{0}\left(y_{i}^{0}, P^{0}\right)-v^{1}$ $\left(y_{i}^{1}, P^{1}\right)>0$. However, the consumer will reject the idea of privatisation of extension if $v^{0}\left(y_{i}^{0}, P^{0}\right)-v^{1}\left(y_{i}^{1}, P^{1}\right)<0$.

The concept of willingness to pay has commonly looked at the utility maximisation of consumers. Relevant literature has shown that it can also be extended to producers, meaning that the producers' profit maximisation decision is subject to a given production function (Munthali, 2013). Agribusiness and various service providers assess the consumers' willingness to pay for a new product or service before production (Wegary, 2013). A farmers' desire to pay for extension services may be borne out of his/ her quest to continually receive proven and relevant information from extension that increases his production and income (Temesgen \& Tola, 2015). However, the risk of using hypothetical methods such as CVM is that the respondents (farmers) state a higher value than their true WTP for the services offered to them (Mwaura et al, 2010). 
S. Afr. J. Agric. Ext.

Vol. 47 No. 4, 2019: 29 - 45

http://dx.doi.org/10.17159/2413-3221/2019/v47n4a524
Loki, Mudhara,

Pakela-Jezile \& Mkhabela

(License: CC BY 4.0)

\section{METHODOLOGY}

\subsection{Study area and data collection}

The study was undertaken in seven districts in the Eastern Cape and KwaZulu-Natal provinces. The seven districts include five from the Eastern Cape (Amathole, Joe Gqabi, Chris Hani, O.R. Tambo, Alfred Nzo) and two from KwaZulu-Natal (Harry Gwala and Umgungundlovu). The reason for the imbalance in the number of districts from each province was due to the remedial provincial programmes organised by the Department of Agriculture in KwaZulu-Natal which forced the farmers to forfeit their participation in the study and the researcher did not have the necessary funds to reschedule. The selection criteria of the district municipalities was aligned to their contribution to the province's total Gross Domestic Product (GDP) (DAFF, 2016). For example, Umgungundlovu is the second largest contributor to the GDP in KwaZulu-Natal after Ethekwini Metropolitan Municipality and houses a significant number of farmers that not only produce for household consumption, but for the markets as well (Statistics South Africa (StatsSA), 2016). Amathole, O.R.Tambo, Chris Hani and Joe Gqabi districts are known to have farmers that produce a significant number of livestock, small stock, and their by-products in South Africa (StatsSA, 2016).

The study employed a quantitative research approach. A list comprising the number and location of smallholder farmers was acquired from the Department of Agriculture, Forestry and Fisheries (DAFF) and the Agricultural Research Council (ARC) in 2017. This permitted the researcher to employ simple random sampling and select 111 land reform beneficiaries. The respondents were randomly selected to avoid biasness and to give the individuals an equal chance of becoming part of the sample. Data were collected using a structured interview schedule and a semi-structured interview guide for focus group discussions.

\subsection{Data Analysis}

\subsubsection{Demographic and socio-economic characteristics}

The study employed comparative statistics such as Chi-square and T-test analyses to establish the relationship between the socio-economic characteristics of the respondents and the willingness of smallholder farmers to pay for extension services.

\subsubsection{Probit regression}

The response variable, farmers' willingness to pay for agricultural extension services, is quantitative in nature. A hypothetical price of R250 per month for extension services was established as a base to investigate whether individual farmers would be willing to pay. The appropriate model is a discrete choice model such as the probit model (Gujarati, 2004). Following Gujarati (2004), to motivate the probability model, the decision of the farmer to pay for extension services or not depends on an unobservable utility index $l$. This utility index is a latent variable, which is determined by a number of explanatory variables. The index, $l_{i}$ is expressed as:

$l_{i}=\beta_{1}+\beta_{2} X_{i}$

In establishing the relation between the unobservable utility index and the actual decisionmaking on willingness to pay, a threshold level of the utility index is assumed, say $I_{i}^{*}$. 
if $I_{i}>I_{i}^{*}, l=1$

if $I_{i} \leq I_{i}^{*}, l=0$

According to Ulimwengu and Sanyal (2011), given the assumption of normality, the probability that $I_{i}^{*}$ is less than or equal to $I_{i}$ can be computed from the standardized normal cumulative density function (CDF) as:

$P_{i}=P(Y=1 \mid X)=P\left(l_{i}^{*} \leq l_{i}\right)=P\left(Z_{i} \leq \beta_{1}+\beta_{2} X_{i}, \ldots \ldots \ldots \beta_{n}\right)=F\left(\beta_{1}+\right.$

$\left.\beta_{2} X_{1} \ldots \ldots \ldots \beta_{n} \beta_{n}\right)$

Where $P(Y=1 \mid X)$ means the probability that an event occurs given the values of the explanatory variables and where $Z_{i}$ is the standardized normal value, i.e. $\left(Z \sim \mathrm{N}\left(O, \sigma^{2}\right)\right)$. F is the standard normal CDF (Ulimwengu \& Sanyal 2011; Wegary, 2013). Taking the inverse of the $\mathrm{CDF}$ gives:

$I_{i}=F^{-1}\left(P_{i}\right)=\beta_{1}+\beta_{2} X_{1} \ldots \ldots \ldots \beta_{n} \beta_{n}$

Table 1: Relationships between the dependent variable and the explanatory variables

\begin{tabular}{|c|c|c|}
\hline Dependent variable & Measure & \\
\hline $\begin{array}{l}\text { Willingness to pay for } \\
\text { extension services }\end{array}$ & $\begin{array}{l}1=\text { Willingness to pay } \\
0=\text { Unwilling to pay }\end{array}$ & \\
\hline Independent variable & Measure & Expected outcome \\
\hline Type of farmers & Dummy - Part time $=0$ Full time $=1$ & + \\
\hline Farmer experience & Continuous - years & - \\
\hline Age groups & Continuous - years & + \\
\hline Gender & Dummy - Female $=0$, Male $=1$ & - \\
\hline Level of education & $\begin{array}{l}\text { Categorical }- \text { No education }=0, \text { Primary }=1, \text { Secondary }= \\
2, \text { Tertiary }=3\end{array}$ & + \\
\hline Farming enterprise & $\begin{array}{l}\text { Categorical Crop farming }=0, \text { Livestock farming }=1 \text {, } \\
\text { Mixed farming }=2\end{array}$ & - \\
\hline Farming seasons & Dummy - Seasonally $=0$, Annually $=1$ & - \\
\hline Farming purpose & $\begin{array}{l}\text { Categorical }- \text { HH Consumption }=0, \text { Selling }=1, \text { Both } \\
\text { selling }=2\end{array}$ & + \\
\hline Farming goals & Not Achieved $=0$, Yes achieved $=1$, & + \\
\hline Agriculture Income & Continuous - Amount/year & + \\
\hline Land Ownership & Dummy - Does not own land $=0$, Owns Land $=1$ & + \\
\hline Land Size & Continuous (Hectares) & + \\
\hline Land type & Dummy - Communal $=0$, Commercial $=1$ & - \\
\hline Access to extension & Dummy - Difficult $=0$, Easy $=1$ & - \\
\hline Extension visit & $\begin{array}{l}\text { Categorical - Weekly }=0, \text { Monthly }=1 \text {, Quarterly }=2 \text {, } \\
\text { Annually }=3\end{array}$ & + \\
\hline Response of Ext. officers & $\begin{array}{l}\text { Categorical }- \text { Instant }=0, \text { Takes time }=1, \text { Neutral }=2, \\
\text { Don't respond }=3\end{array}$ & + \\
\hline Change in farm Practices & $\begin{array}{l}\text { Dummy - No change in practices }=0 \text {, Change in practices } \\
=1\end{array}$ & - \\
\hline Changes in yield & Dummy - No change in Yield $=0$, Change in Yield $=1$ & + \\
\hline Privatisation of extension & $\begin{array}{l}\text { Dummy - Should not privatise }=0, \text { Should be privatised }= \\
1\end{array}$ & + \\
\hline$R i+\varepsilon t=$ Error term & & \\
\hline
\end{tabular}


S. Afr. J. Agric. Ext.

Vol. 47 No. 4, 2019: 29 - 45

http://dx.doi.org/10.17159/2413-3221/2019/v47n4a524
Loki, Mudhara,

Pakela-Jezile \& Mkhabela

(License: CC BY 4.0)

\section{RESULTS AND DISCUSSION}

\subsection{Demographic information of farmers in the study area}

The section below looks at the socio-economic characteristics and empirical results of the study, paying specific attention to the willingness to pay for extension services and the services they are willing to pay for. The tables below indicate the frequency and statistical distribution of demographic characteristics, farming activities, access to extension services, and how these were important in explaining the relationship between farmers and their willingness to pay for extension services. The study employed Chi-square and T-test analyses to assess the significance through regression of the dependent variable (WTP) of the relationship between the farmers' willingness to pay and their demographic characteristics.

Table 2: Demographic information of farmers in the study area

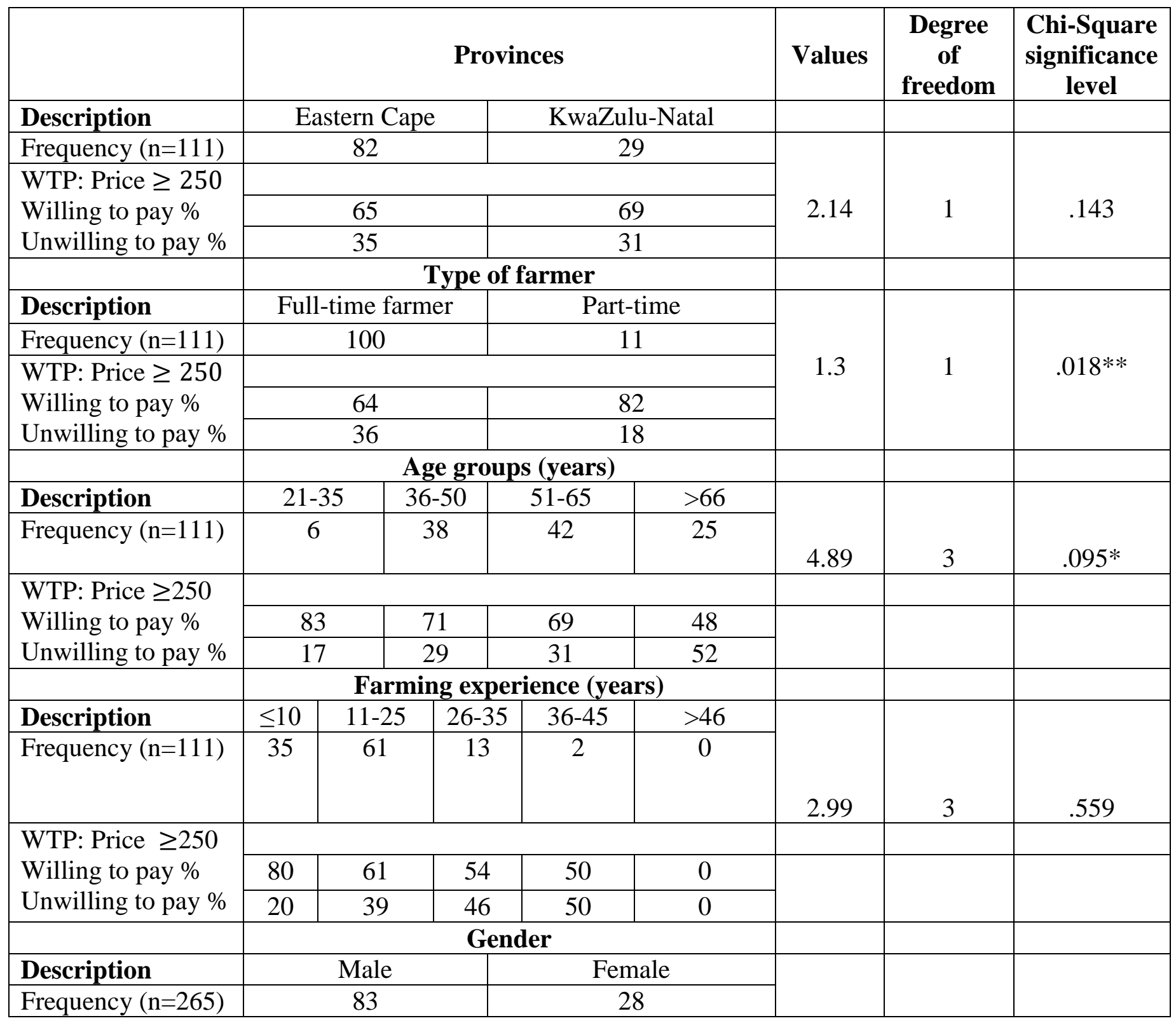




\begin{tabular}{|c|c|c|c|c|c|c|c|}
\hline \multirow{3}{*}{$\begin{array}{l}\text { WTP: Price } \geq 250 \\
\text { Willing to pay }(\%) \\
\text { Unwilling to pay } \%\end{array}$} & & & & & \multirow{4}{*}{.025} & \multirow{5}{*}{1} & \multirow{4}{*}{.874} \\
\hline & \multicolumn{2}{|c|}{70} & \multicolumn{2}{|c|}{54} & & & \\
\hline & \multicolumn{2}{|c|}{30} & \multicolumn{2}{|c|}{46} & & & \\
\hline & \multicolumn{4}{|c|}{ Marital status } & & & \\
\hline Description & Single & Married & Divorced & Widowed & & & \\
\hline \multirow[t]{2}{*}{ Frequency $(n=265)$} & 18 & 76 & 7 & 10 & & & \\
\hline & & & & & 2.6 & 3 & .456 \\
\hline \multirow{4}{*}{$\begin{array}{l}\text { WTP: Price } \geq 250 \\
\text { Willing to pay }(\%) \\
\text { Unwilling to pay } \%\end{array}$} & & & & & & & \\
\hline & 78 & 63 & 71 & 60 & & & \\
\hline & 22 & 37 & 29 & 40 & & & \\
\hline & \multicolumn{4}{|c|}{ Level of education } & & & \\
\hline Description & $\begin{array}{l}\text { No } \\
\text { Education }\end{array}$ & Primary & Secondary & Tertiary & & & \\
\hline \multirow[t]{2}{*}{ Frequency } & 4 & 22 & 54 & 31 & & & \\
\hline & & & & & 2.22 & 3 & $.013 * *$ \\
\hline \multirow{3}{*}{$\begin{array}{l}\text { WTP: Price } \geq 250 \\
\text { Willing to pay } \% \\
\text { Unwilling to pay } \%\end{array}$} & & & & & & & \\
\hline & 50 & 55 & 69 & 71 & & & \\
\hline & 50 & 45 & 31 & 29 & & & \\
\hline
\end{tabular}

Note: $* * *=p<0.001 ; * *=p<0.05 ; *=p<0.1$

Source: Field survey, 2018

As indicated in Table 2, age of the farmers (divided into groups) was found to be statistically significant in relation to the willingness to pay for extension services. Furthermore, among the age groups, farmers between the ages of 36 and 50 (63\%), as well as between 51 and 65 (55\%) years had the capacity and were willing to pay for extension services compared to their counterparts (> 66 years). Education was found to be statistically significant in relation to the willingness to pay as more farmers who had secondary and tertiary levels of education were willing to pay than illiterate counterparts were. The findings are similar to Bester's (2008) findings with regards to farmers being able to be flexible and open to new ideas.

\subsection{Agricultural income and land size}

Agricultural income is an important indicator; it gives information on the viability or lack of it in the agricultural sector (DAFF, 2016). Agricultural income refers to the total income (cash or in kind) earned from agricultural products sold and other income (StatsSA, 2016).

Table 3: Agricultural income and land size in the study area

\begin{tabular}{|l|c|c|c|}
\hline \multicolumn{1}{|c|}{ Explanatory variables } & \multicolumn{2}{|l|}{$\begin{array}{l}\text { WTP: } \\
\text { Price (hypothetical) }=\mathrm{R} 250\end{array}$} & $\begin{array}{c}\text { T-test for equality of } \\
\text { means } \\
\end{array}$ \\
\cline { 2 - 3 } & $\begin{array}{c}\text { Yes }= \\
\mathrm{P} \geq \mathrm{R} 250\end{array}$ & $\begin{array}{c}\mathrm{No}= \\
\mathrm{P} \leq \mathrm{R} 249\end{array}$ & \\
\hline Total agriculture income $(\mathrm{R})$ & 733155.03 & 607293.68 & $.023^{* *}$ \\
\hline Land Size (ha) & 670.48 & 409.60 & $.036^{* *}$ \\
\hline
\end{tabular}

Note: $* * *=\mathrm{p}<0.001 ; * *=\mathrm{p}<0.05 ; *=\mathrm{p}<0.1$

Source: Field survey, 2018 
The average agricultural income of farmers who were willing to pay is higher than that for farmers who were not willing to pay. The difference is statistically significant at $5 \%$, presumably owing to the fact that the variance of income for each subgroup is quite high. The same goes for the comparison of average land size; the average land size of farmers who are willing to pay was higher than that for farmers who were not willing to pay, and the difference was significant at $5 \%$. The mean amount generated in the study area was approximately R733 155.03.

\subsection{Farming characteristics}

Each individual farm has its own specific characteristics, which arise from variations in resource endowments and family circumstances. The household, its resources, and the resource flows and interactions at this individual farm level are together referred to as farm activities. The study employed a Chi-square test to assess the relationship between farming activities and farmers' willingness to pay for extension in the study area.

Table 4: Farmer activities

\begin{tabular}{|c|c|c|c|c|c|c|}
\hline & \multicolumn{3}{|c|}{ Farming enterprises } & \multirow[t]{2}{*}{ Values } & \multirow[t]{2}{*}{$\begin{array}{l}\text { Degree of } \\
\text { freedom }\end{array}$} & \multirow[t]{2}{*}{$\begin{array}{l}\text { Chi-Square } \\
\text { significance }\end{array}$} \\
\hline Description & $\begin{array}{c}\text { Crop } \\
\text { farming }\end{array}$ & $\begin{array}{c}\text { Livestock } \\
\text { farming }\end{array}$ & $\begin{array}{c}\text { Mixed } \\
\text { farming }\end{array}$ & & & \\
\hline Frequency $(\mathrm{n}=111)$ & 7 & 29 & 75 & \multirow{5}{*}{2.32} & \multirow{5}{*}{2} & \multirow{5}{*}{$.090 *$} \\
\hline WTP: Price $\geq 250$ & & & & & & \\
\hline Willing to pay (\%) & 71 & 59 & 32 & & & \\
\hline Unwilling to pay (\%) & 29 & 41 & 68 & & & \\
\hline & \multicolumn{3}{|c|}{ Farming season } & & & \\
\hline Description & Seasonal & Annual & Both & \multirow[t]{5}{*}{.511} & \multirow[t]{5}{*}{2} & \multirow[t]{5}{*}{.775} \\
\hline Frequency $(n=111)$ & 9 & 72 & 30 & & & \\
\hline WTP: Price $\geq 250$ & & & & & & \\
\hline Willing to pay (\%) & 44 & 69 & 63 & & & \\
\hline Unwilling to pay (\%) & 56 & 31 & 37 & & & \\
\hline & \multicolumn{3}{|c|}{ Farming reasons } & & & \\
\hline Description & HH Cons & Selling & $\begin{array}{l}\text { Both sell } \\
\& \text { Cons }\end{array}$ & \multirow{5}{*}{1.24} & \multirow{5}{*}{2} & \multirow{5}{*}{.538} \\
\hline Frequency $(\mathrm{n}=111)$ & 1 & 33 & 77 & & & \\
\hline \multirow{4}{*}{$\begin{array}{l}\text { WTP: Price } \geq 250 \\
\text { Willing to pay }(\%) \\
\text { Unwilling to pay }(\%)\end{array}$} & & & & & & \\
\hline & 100 & 76 & 61 & & & \\
\hline & 0 & 24 & 39 & & & \\
\hline & Achie & ing farmir & goals & & & \\
\hline Description & Yes & & No & \multirow{5}{*}{4.97} & \multirow{5}{*}{1} & \multirow{5}{*}{$.026 * *$} \\
\hline Frequency $(n=111)$ & 89 & & 22 & & & \\
\hline \multirow{4}{*}{$\begin{array}{l}\text { WTP: Price } \geq 250 \\
\text { Willing to pay }(\%) \\
\text { Unwilling to pay }(\%)\end{array}$} & & & & & & \\
\hline & 66 & & 64 & & & \\
\hline & 34 & & 36 & & & \\
\hline & \multicolumn{3}{|c|}{ Land ownership } & & & \\
\hline Description & Yes & & No & & & \\
\hline
\end{tabular}




\begin{tabular}{|l|c|c|c|c|c|}
\hline Frequency $(\mathrm{n}=111)$ & 49 & 62 & \multirow{2}{*}{4.74} & \multirow{2}{*}{.491} \\
\hline WTP: Price $\geq 250$ & & & & \\
\cline { 2 - 3 } Willing to pay (\%) & 63 & 68 & & \\
\cline { 2 - 3 } Unwilling to pay (\%) & 37 & 32 & & \\
\hline
\end{tabular}

Note: $* * *=\mathrm{p}<0.001 ; * *=\mathrm{p}<0.05 ; *=\mathrm{p}<0.1$

Source: field survey, 2018

As represented in Table 4, farming enterprises, which were comprised of crop, livestock and mixed farming, were found to be statistically significant at $5 \%$ in relation to the willingness to pay. Similarly, farming goals were statistically significant at $5 \%$ to the willingness to pay. The assumption is that the farmers understand the value of fee for services concept and that paying for services would improve the quality of extension received and subsequently help improve yield returns and achieve farming goals (Njoko, 2014).

\subsection{Extension services in the study area}

In South Africa, agricultural extension services are the most common forms of public sector support for knowledge diffusion and learning. The concept of extension services sector involves agricultural experts, who teach improved methods of farming in both livestock and cropping enterprises, demonstrate innovations, organise farmer meetings and markets (Schwartz, 1994). Smallholder farmers are the primary beneficiaries.

Table 5 presents results on farmers' access to extension services. The majority (67\%) of farmers who had access to extension services indicated that it was easy to contact extension officials whenever they needed technical assistance and this was statistically significant at 5\% to the willingness to pay. Furthermore, privatisation of extension services was statistically significant at $1 \%$ to the willingness to pay for extension services. This indicates that farmers foresee the benefits of pay for extension services, which include technical efficiency, and extension officials who are profit orientated. The findings are similar to those made by Zwane (2016) that the reason/s farmers are willing to pay for private extension is that they come with a host of benefits such as greater operational efficiency, cost-effectiveness, as well as accountability of extension officers to perform and produce results.

Table 5: Access to extension services

\begin{tabular}{|c|c|c|c|c|c|}
\hline & $\begin{array}{l}\text { Access } \\
\text { Access }\end{array}$ & $\begin{array}{l}\text { Sion services } \\
\text { sion services }\end{array}$ & Values & $\begin{array}{l}\text { Degree of } \\
\text { freedom }\end{array}$ & $\begin{array}{l}\text { Chi-Square } \\
\text { significance }\end{array}$ \\
\hline Description & Yes & $\mathrm{No}$ & \multirow{5}{*}{.145} & \multirow{5}{*}{ 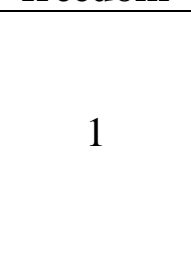 } & \multirow{5}{*}{.608} \\
\hline Frequency $(n=111)$ & 110 & 1 & & & \\
\hline \multirow{4}{*}{$\begin{array}{l}\text { WTP: Price } \geq 250 \\
\text { Willing to pay }(\%) \\
\text { Unwilling to pay }(\%)\end{array}$} & & & & & \\
\hline & 66 & 0 & & & \\
\hline & 34 & 100 & & & \\
\hline & \multicolumn{2}{|c|}{$\begin{array}{l}\text { How is the access to } \\
\text { extension services? }\end{array}$} & & & \\
\hline Description & Easy & Difficult & \multirow[t]{4}{*}{.145} & \multirow[t]{4}{*}{1} & \multirow[t]{4}{*}{$.099^{*}$} \\
\hline Frequency $(\mathrm{n}=111)$ & 81 & 29 & & & \\
\hline \multirow{2}{*}{$\begin{array}{l}\text { WTP: Price } \geq 250 \\
\text { Willing to pay }(\%)\end{array}$} & & & & & \\
\hline & 67 & 66 & & & \\
\hline
\end{tabular}




\begin{tabular}{|c|c|c|c|c|c|}
\hline Unwilling to pay (\%) & 33 & 34 & & & \\
\hline & \multicolumn{2}{|c|}{$\begin{array}{c}\text { Any changes in farm } \\
\text { practices? }\end{array}$} & & & \\
\hline Description & Yes & No & \multirow{5}{*}{1.85} & \multirow{5}{*}{1} & \multirow{5}{*}{.947} \\
\hline Frequency $(\mathrm{n}=111)$ & 92 & 19 & & & \\
\hline \multirow{3}{*}{$\begin{array}{l}\text { WTP: Price } \geq 250 \\
\text { Willing to pay }(\%) \\
\text { Unwilling to pay }(\%)\end{array}$} & & & & & \\
\hline & 68 & 53 & & & \\
\hline & 32 & 47 & & & \\
\hline & \multicolumn{2}{|c|}{$\begin{array}{l}\text { Any difference in yield/ } \\
\text { production outcome? }\end{array}$} & & & \\
\hline Description & Yes & No & \multirow{5}{*}{.488} & \multirow{5}{*}{1} & \multirow{5}{*}{.860} \\
\hline Frequency $(\mathrm{n}=111)$ & 91 & 20 & & & \\
\hline \multirow{4}{*}{$\begin{array}{l}\text { WTP: Price } \geq 250 \\
\text { Willing to pay }(\%) \\
\text { Unwilling to pay }(\%)\end{array}$} & & & & & \\
\hline & 68 & 55 & & & \\
\hline & 32 & 46 & & & \\
\hline & & $\begin{array}{l}\text { ion be } \\
\text { l? }\end{array}$ & & & \\
\hline Description & Yes & No & & & \\
\hline Frequency $(\mathrm{n}=111)$ & 64 & 47 & & & \\
\hline WTP: Price $\geq 250$ & & & 71.66 & 1 & $.001 * * *$ \\
\hline Willing to pay (\%) & 98 & 79 & & & \\
\hline Unwilling to pay (\%) & 2 & 21 & & & \\
\hline
\end{tabular}

Note: $* * *=\mathrm{p}<0.001 ; * *=\mathrm{p}<0.05 ; *=\mathrm{p}<0.1$

Source: field survey, 2018

\subsection{Extension services farmers are willing to pay for}

In its simplest form and definition, willingness to pay is the measure of the maximum amount of money a consumer/ farmer is willing to give by obtaining goods or services of a good quality (Bello \& Salau, 2009). Table 6 shows the different services farmers are willing to pay for and the amounts. As alluded earlier, information and empirical evidence on farmer's willingness to pay, which extension services they are willing to pay for, and at what price is scanty in South Africa. Table 6 indicates which services farmers in the Eastern Cape and KwaZulu-Natal provinces are willing to pay for and at what price. Using T-test analysis, the results are shown below.

Table 6: Extension services and the mean amount farmers are willing to pay for

\begin{tabular}{|l|c|c|}
\hline Explanatory variable & $\begin{array}{c}\text { Mean } \\
\text { (R/ Per- } \\
\text { Month) }\end{array}$ & $\begin{array}{c}\text { T-test for } \\
\text { equality of } \\
\text { means } \\
\text { Sig }\end{array}$ \\
\hline Maximum amount willing to pay for extension services & 618.89 & $.005^{* * *}$ \\
\hline Maximum amount willing to pay for visitation period & 481.07 & $.004^{* * *}$ \\
\hline Maximum amount willing to pay for production skills & 414.37 & .164 \\
\hline Maximum amount willing to pay for marketing skills & 445.51 & $.001^{* * *}$ \\
\hline Maximum amount willing to pay for risk management & 391.12 & .145 \\
\hline Maximum amount willing to pay for disease manage & 425.71 & .468 \\
\hline
\end{tabular}




\begin{tabular}{|l|c|c|}
\hline $\begin{array}{l}\text { Maximum amount willing to pay for crop and livestock } \\
\text { management }\end{array}$ & 429.39 & $.021^{* *}$ \\
\hline $\begin{array}{l}\text { Maximum amount willing to pay for fertilizer and } \\
\text { vaccine application }\end{array}$ & 352.86 & .623 \\
\hline Maximum amount willing to pay for record keeping & 390.65 & $.056^{*}$ \\
\hline $\begin{array}{l}\text { Maximum amount willing to pay for individual training } \\
\text { and visits }\end{array}$ & 418.52 & $.085^{*}$ \\
\hline $\begin{array}{l}\text { Maximum amount willing to pay for group training and } \\
\text { visits }\end{array}$ & 425.52 & $.051^{* *}$ \\
\hline $\begin{array}{l}\text { Maximum amount willing to pay for mass media as } \\
\text { source information }\end{array}$ & 391.43 & .951 \\
\hline $\begin{array}{l}\text { Maximum amount willing to pay for facilitation as a } \\
\text { teaching method }\end{array}$ & 299.47 & .159 \\
\hline $\begin{array}{l}\text { Maximum amount willing to pay for demonstrations as a } \\
\text { teaching method }\end{array}$ & 488.03 & $.003^{* * *}$ \\
\hline
\end{tabular}

Note: $* * *=\mathrm{p}<0.001 ; * *=\mathrm{p}<0.05 ; *=\mathrm{p}<0.1$

Source: Field survey, 2018

As demonstrated in Table 6, after establishing willingness to pay, farmers indicated the price and type of services for which they were willing to pay. On average, farmers in the study area were willing to pay R618.89 per month (pm) for extension services in crop and animal husbandry. For visitation periods, farmers were willing to pay an average fee of R481.07 pm for extension officers who visits them on a monthly basis. Farmers also preferred an extension officer who would visit them and communicate technologies to them in groups (R425.52 pm) and individually (R418.52 pm). Furthermore, farmers preferred demonstrations as the main method to deliver agriculture technologies and they were willing to pay an average amount of R488.03 pm.

Employing the T-test on Table 6, farmers felt that some services were urgent (highly significant) to their farming and they were willing to pay for them. These services included marketing (R445.51 pm) as well as crops and livestock management (R429.39 pm).

\subsection{Empirical results of the probit model}

Table 7 shows the results from the probit regression model that was run to investigate the factors that influence land reform beneficiaries' willingness to pay for extension services. Willingness to pay was used as a dependent variable, which was a dummy variable where 1 represented the farmers who were willing to pay for extension and 0 for farmers who were not willing to pay for extension services. The results are presented in Table 7.

Table 7: Factors influencing farmers' willingness to pay for extension services

\begin{tabular}{|l|c|c|c|c|}
\hline Willingness to pay for extension services & Coefficient & $\begin{array}{c}\text { Robust } \\
\text { Std. Err. }\end{array}$ & $\mathbf{Z}$ & $\mathbf{P}>\mathbf{z}$ \\
\hline Farmer type & .8631117 & .3049947 & 2.83 & $0.005^{* *}$ \\
\hline Farmer experience & .1033147 & .1489763 & 0.69 & 0.488 \\
\hline Age groups & -.3108833 & .1403793 & -2.21 & $0.027^{*}$ \\
\hline Gender & -.1685664 & .2412904 & -0.70 & 0.485 \\
\hline Marital status & -.0456795 & .1329028 & -0.34 & 0.731 \\
\hline
\end{tabular}




\begin{tabular}{|l|r|r|r|c|}
\hline Level of education & -.0542694 & .1253966 & -0.43 & \multicolumn{1}{c|}{0.665} \\
\hline Farming enterprise & .0714885 & .1895641 & 0.38 & 0.706 \\
\hline Farming season & .5076662 & .2130887 & 2.38 & \multicolumn{1}{c|}{$0.017^{*}$} \\
\hline Farming goals & -.3275927 & .2010245 & -1.63 & \multicolumn{1}{c|}{0.103} \\
\hline Farm goals achieved & .6158427 & .2502532 & 2.46 & \multicolumn{1}{c|}{$0.014^{*}$} \\
\hline Agric income & $-1512 \mathrm{e}-07$ & $1.00 \mathrm{e}-07$ & -3.12 & $0.002^{* * *}$ \\
\hline Land ownership & -.0666157 & .2194024 & -0.30 & 0.761 \\
\hline Land size & .0010292 & .0002869 & 3.59 & $0.001^{* * *}$ \\
\hline Land type & -.1163733 & .2434998 & -0.48 & 0.633 \\
\hline Access to extension & .4742006 & .2385187 & 1.99 & $0.047^{*}$ \\
\hline Extension visit & .1273775 & .1187857 & 1.07 & 0.284 \\
\hline Response of extension officers & -.3085125 & .1116263 & -2.76 & $0.006^{* *}$ \\
\hline Change in farm practices & -1.058301 & .4030892 & -2.63 & $0.009^{* *}$ \\
\hline Changes in yield & .4745995 & .3665985 & 1.29 & 0.195 \\
\hline Privatisation of extension & 2.444119 & .2447612 & 9.99 & $0.001 * * *$ \\
\hline Constant & -.2189632 & 1.006589 & -0.22 & 0.828 \\
\hline
\end{tabular}

Source: Field survey, 2018

From the 19 variables fitted in the probit logistic model, 10 variables had a significant influence on identifying the characteristics associated with the willingness to pay for extension services. Farmer type, age, farming seasons, goals, agricultural income, land size, type, access to extension services, response of extension to farmer needs, change in farmers' practices, and privatisation had a significant influence on the willingness of farmers to pay. The Pseudo R2 suggests that the model is reasonably powerful and that the results could be used with confidence.

In general, the coefficients of the probit regression cannot be interpreted from the initial output, thus the need to interpret the marginal effects of the regressors (Greene, 2000). That is to say, how much the (conditional) probability of the outcome variable changes when there is a change in the value of variables, holding all other variable constant at some values. This is different from the linear regression case where a direct interpretation can be estimated for the coefficients (Gujarati, 2004). This is because, with linear regression, the regression coefficients (output) are the marginal effects, whereas in the probit regression, there is an additional step of computing required to get the marginal effects (Greene, 2000). This is the notion of marginal effects measure and is shown in Table 8.

Table 8: Marginal effects of the probit regression model

\begin{tabular}{|l|l|l|l|l|}
\hline Willingness to pay for extension services & \multicolumn{1}{|c|}{$\mathbf{d y} / \mathbf{d x}$} & Std. Err. & \multicolumn{1}{|c|}{$\mathbf{Z}$} & \multicolumn{1}{|c|}{$\mathbf{P > \mathbf { z }}$} \\
\hline Farmer type & 0.333643 & .1095 & 3.05 & $0.002 * * *$ \\
\hline Farmer experience & 0.0402112 & .05795 & 0.69 & 0.488 \\
\hline Age groups & -0.1209992 & .05472 & -2.21 & $0.027 * *$ \\
\hline Gender & 0.0649615 & .09206 & -0.71 & 0.480 \\
\hline Marital status & -0.017779 & .05169 & -0.34 & 0.731 \\
\hline Level of education & -0.0211222 & .04883 & -0.43 & 0.665 \\
\hline Farming systems & 0.0278241 & .07374 & 0.38 & 0.706 \\
\hline Farming season & 0.1975893 & .08365 & 2.36 & $0.018 * *$ \\
\hline
\end{tabular}




\begin{tabular}{|l|l|l|l|l|}
\hline Farming goals & -0.1275027 & .07864 & -1.62 & 0.105 \\
\hline Farm goals achieved & -0.2406287 & .09606 & 2.51 & $0.012^{* *}$ \\
\hline Agric income & $-0.1002 \mathrm{e}-07$ & .00000 & -3.13 & $0.002^{* * *}$ \\
\hline Land ownership & -0.025941 & .08544 & -0.30 & 0.761 \\
\hline Land size & 0.0004006 & .00011 & 3.62 & $0.001^{* * *}$ \\
\hline Land type & -0.0453624 & .09478 & -0.48 & 0.632 \\
\hline Access to extension & 0.1845641 & .0927 & 1.99 & $0.046^{*}$ \\
\hline Extension visit & .0495767 & .04623 & 1.07 & 0.284 \\
\hline Response of extension officers & -0.1200764 & -04351 & -2.76 & $0.006^{* *}$ \\
\hline Change in farm practices & -0.3586407 & .11108 & -3.23 & $0.001^{* *}$ \\
\hline Changes in yield & 0.1847193 & .14278 & 1.29 & 0.196 \\
\hline Privatisation of extension & 0.7634686 & .04755 & 16.06 & $0.001^{* * *}$ \\
\hline$*$ dy/dx is for discrete change of dummy variable from 0 to 1 & & \\
\hline
\end{tabular}

\subsubsection{Farmer age and farm experience}

Farmers in this survey were either full-time or part-time farmers. According to Table 8, being a farmer, either full-time or part-time, was significant at $1 \%$ to the willingness to pay, and if a farmer decides to move from part-time to full-time farming, their willingness to pay for extension services increases by 0.33 unit (33\%). This may be motivated by an increase in his farm income, access to larger farming land, funding, or retrenchment from their everyday occupation (Mniki, 2009).

Table 8 also indicated that the age groups in which farmers were categorised was significant at $5 \%$ to the willingness and the coefficient was negative suggesting that the relationship was inversely proportional. This means that when a farmer moves out of a younger age group to an older one, their willingness to pay for services decrease by $31 \%$ (-0.31 units). This may be a result of the farmer believing that with increasing age and time in farming, the farmer has adequate expertise and therefore does not require advisory services (Alemu, 2012). This may also explain why farming experience was not significant, since the higher the experience of the farmer, the less likely they are willing to learn something new or change their farming methods, for example, pay to receive services. Moreover, education was also found to be insignificant. It could be proposed that the higher the educational level of farmers, the more they are not willing to pay because they feel they can acquire information on their own (Sikwela, 2013).

\subsubsection{Farming season, goals, agricultural income and land size}

As represented in Table 8, farmers in this survey practiced farming either seasonally or annually, the significance level to the willingness to pay was at $5 \%$, and the coefficient was positive. This means there was a positive relationship between the willingness to pay and farming seasons such as the probability of a farmer moving from an annual to a seasonal farmer associated with willingness to pay increases by $19 \%$. Achieving farming goals were significant at $5 \%$ and the coefficient was negative. The means that the probability of achieving farming goals associated with farmers' willingness to pay for services decreases by $24 \%$ (-0.24 units). This implies that if a farmer achieves one set goal (short, medium and long-term goal) their willingness to pay more for that extension service decreases. 
Agricultural income was significant at $1 \%$ to the willingness to pay for extension services, however, the coefficient was negative. This indicates that the marginal effect on probability of $y=1$ associated agricultural income increased by $100 \%$. This means that farmers who made a profit from their produce were no longer willing to pay for extension services. This may be as a result of the farmer not feeling the need to pay more after an increase in his income as this may reduce his anticipated profit. Furthermore, land size was significant at a $1 \%$ level and the coefficient was positive. This implies that the relationship between land size and farmers' willingness to pay was directly proportional and the marginal effect on the probability of $y=1$ associated with land size increases by $0.04 \%$. In other words, this means an increase of one hectare in land size increases the willingness to pay by 0.04 units/ price.

\subsubsection{Access to extension, response change in farming practices and privatisation}

Individual farmers were asked how their extension services are and the relationship between these two role players was found to be positive and significant (Table 8). Access to extension services, whenever you need them, was significant at $5 \%$ to the willingness to pay and the coefficient were positive. The relationship is positive, and this indicates that that the expected difference in the probability of $y=1$ associated with access to extension to pay for extension increases by $18 \%$. This means that if access to extension services is easy, farmers' willingness to pay for services increases by $18 \%$. This is because if extension officials are easily accessible, they can help farmers deal with their farming challenges quickly, especially in cases of emergency (Afful \& Lategan, 2014; Labarthe \& Laurent, 2013).

The time taken by extension officials to respond to farmers was significant at $5 \%$ to the willingness to pay for extension services. However, the coefficient was negative which indicates that the expected difference in the probability of $y=1$ associated with the response of extension services decreases by $18 \%$. This means that the relationship between the response of extension officials to farmers' queries was found to be inversely proportional. The farmers' willingness to pay decreased presumably since farmers do not entirely trust the response of extension officers or if they will get the help they need (Umhlaba Rural Services, 2006).

As represented in Table 8, change in farm practices were found to be significant at $1 \%$ and the coefficient was negative in relation to the willingness to pay for extensions services. Changes in farm practices/ methodologies had an inversely proportional relationship to the willingness to pay and the expected difference in probability of $y=1$ decrease was $35 \%$. The reason or this may be due to the fact that the farmers do not see the need to pay more when they have learned a new skill set.

Farmers were in favour of privatisation of extension and as shown in Table 8, the relationship between privatisation and farmers' willingness to pay was highly significant at $1 \%$. Farmers argued that if extension were to be privatised, they would pay for those services provided by private companies (Hellin, 2012). The relationship between privatisation and willingness to pay was positive and it stated a change in extension supplier (from public to private) increases the probability of a farmer to pay by $76 \%$ ( 0.76 units). The reasons for this are found in literature and the argument is that if extension services were privatised, they would cut down the fruitless expenditure championed by the government sector, get rid of the top-down approach, and increase efficiency which improves the quality of extension services provided (Labarthe \& Laurent, 2013; Uddin \& Qijie, 2013) 


\section{CONCLUSION AND RECOMMENDATIONS}

The study was inspired by the lack of reliable and detailed empirical data on smallholder farmers' willingness to pay for extension services, and types of services they are willing to pay for. The scarcity of this information has derailed the commercialisation prospects of smallholder farmers in the Eastern Cape and KwaZulu-Natal provinces in South Africa. The study concluded that farmers were in favour of privatisation as they felt it would improve their farm returns. Inevitably, the idea of privatising extension services meant that farmers had the capacity and were willing to pay. Furthermore, farmers preferred an extension officer who would visit them monthly and communicate technologies to them as a group and through demonstrations. Results of the survey further indicated that famers needed assistance on the most included marketing, livestock management, and record keeping. From the results of the probit regression, it became evident that farmers who were likely to pay appeared to be those who practiced farming on a full-time basis, who are younger, with large farm size (land), who had access to extension, and who saw changes in their farming practises.

Based on the findings, the following recommendations are put forward:

- The study established that age, land size and easy access to extension services are key farmer attributes influencing the willingness to pay for the services. For successful intervention, any extension services provider should take note of such characteristics, as farmers who exhibit such traits will appreciate the services. Farmers with such characteristics should act as innovators upon which others could learn from.

- For land reform beneficiaries who receive grants for farming from the government, an immediate but slow introduction of a fee-based extension services should be embarked upon.

- The study established that land was one of the significant factors with willingness to pay for extension services, therefore efforts leading to giving land reform farmers' tittle deeds and full ownership of the land they farm on is ideal for privatisation.

- The study also investigated the extension services/ technologies that farmers were willing to pay for. However, further research in this area needs to be undertaken as information is still scarce.

- Introducing fee-based extension services or private companies in a space dominated by the public sector and smallholder farmers who have been receiving extension services for free need to be monitored and treated with care.

- International experiences on privatisation of extension services and information on the experiences of commercial farmers in South Africa who practice fee-based services need to be documented and disseminated for public understanding and implementation.

\section{REFERENCES}

AFFUL, D.B. \& LATEGAN, F.S., 2014. Small and medium-scale producers' use and credibility of information sources: Implications for public extension's financial sustainability. S. Afr. J. Agric. Ext., 42(1):27-38. 
AGHOLOR, A.I., 2012. The quality of extension education delivery among livestock farmers in central Eastern Cape. A case study of Nkonkobe Local Municipality. MSc Thesis, University of Fort Hare.

ALEMU, Z.G., 2012. Livelihood strategies in rural South Africa: Implications for poverty reduction, University of the Free State, South Africa. Paper presented to The International Association of Agricultural Economists (IAAE) Triennial Conference. Foz do Iguacu, Brazil.

ANDERSON, J.R. \& FEDER, G., 2004. Agricultural extension: Good intentions and hard realities. World Bank Res. Obs., 19(1):41-60.

BELLO, M. \& SALAU, E.S., 2009. A case for participatory (cost sharing) approach to agricultural extension in Nigeria. J. Agric. Ext., 13(1):84-89.

BESTER, B.J., 2008. Lecture Notes Summary: Agricultural marketing and the importance of agricultural marketing.

DEPARTMENT OF AGRICULTURE, FORESTRY AND FISHERIES (DAFF), 2014. Economic review of the South African agriculture 2014. Available from: www.daff.gov.za

DEPARTMENT OF AGRICULTURE, FORESTRY AND FISHERIES (DAFF), 2016. Economic review of the South African agriculture 2016. Available from: www.daff.gov.za

GÓMEZ, M., MUELLER, B. \& WHEELER, M.K., 2016. Private sector extension activities targeting small farmers in developing countries. MEAS Report. USAID, United States of America.

GREENE, W.H., 2000, Econometric analysis. 4th ed. New Jersey: Prentice-Hall.

GUJARATI, D.N., 2004. Essentials of econometrics. 3rd ed. Singapore: McGraw-Hill.

HELLIN, J., 2012. Agricultural extension, collective action and innovation systems: Lessons on network brokering from Peru and Mexico. J. Agric. Educ. Ext., 18(2):141-159.

KOCH, B.H. \& TERBLANCHÉ, S.E., 2013. An overview of agricultural extension in South Africa. S. Afr. J. Agric. Ext., 41(1):107-117.

LABARTHE, P. \& LAURENT, C., 2013. Privatization of agricultural extension services in the EU: Towards a lack of adequate knowledge for small-scale farms? Food Policy, 38:240252.

LIEBENBERG, F., 2015. Agricultural advisory services in South Africa. Discussion Paper. University of Pretoria, South Africa.

MNIKI, S., 2009, Socio-economic impact of drought induced disasters on farm owners of Nkonkobe Local Municipality. MSc Thesis, University of the Free State.

MUNTHALI, G.T., 2013. Assessing farmers' willingness to pay for improved common bean seed varieties in Malawi: A case study of Kasungu and Dedza Districts. MSc Thesis, University of Pretoria.

MWAURA, F., MUWANIKA, F.R. \& OKOBOI, G., 2010. Willingness to pay for extension services in Uganda among farmers involved in crop and animal husbandry. Paper presented to The Joint 3rd African Association of Agricultural Economists (AAAE) and 
48th Agricultural Economists Association of South Africa (AEASA) Conference. Cape Town, South Africa.

NJOKO, S.L., 2014. Smallholder farmers' willingness and ability to pay for improved irrigation: A case of Msinga Local Municipality, KwaZulu-Natal Province. MSc Thesis, University of KwaZulu-Natal.

OLADELE, O.I., 2008. Factors determining farmers' willingness to pay for extension services in Oyo State, Nigeria. Agricultura Tropica et Subtropica, 41(4):165-170.

RIVERA, W.M., 2001. The invisible frontier: The current limits of decentralization and privatization in developing countries. S. Afr. J. Agric. Ext., 30(1):26-39.

RIVERA, W.M. \& ALEX, G., 2004. The continuing role of government in pluralistic extension systems. JIAEE., 11(3):41-51.

SCHWARTZ, A.L., 1994. The role of the private sector in agricultural extension: Economic analysis and case studies. London: ODI.

SIKWELA, M.M., 2013. The impact of farmer support programmes on market access of smallholder farmers in the Eastern Cape and KwaZulu-Natal provinces, South Africa. $\mathrm{PhD}$ Thesis, University of Fort Hare.

STATISTICS SOUTH AFRICA (StatsSA), 2016. Poverty trends in South Africa: An examination of absolute poverty between 2006 and 2015. Available from: www.statssa.gov.za

TEMESGEN, D. \& TOLA, T., 2015. Determinates of small holder farmers willingness to pay for agricultural extension services: A case study from Eastern Ethiopia. Afr. J. Agric. Res., 10(20):2152-2158.

UDDIN, M. \& QIJIE, G., 2013. Prospects and challenges of privatisation of agricultural extension service in Bangladesh. Asian J. Agric. Rural Dev., 3(7):1-11.

ULIMWENGU, J. \& SANYAL, P., 2011. Joint estimation of farmers' stated willingness to pay for agricultural services. IFPRI Discussion Paper No. 01070. Washington, D.C., United States of America.

UMHLABA RURAL SERVICES, 2006. A national review of the comprehensive agricultural support programme. Available from: http://www.participation.org.za/docs/caspreviewmarch2007.pdf

WEGARY, R., 2013. Farmers' willingness to pay for locally produced potato seed tubers and groundnut seed: The case of Haramaya and Babile districts of East Hararghe zone, Oromia regional state, Ethiopia. PhD Thesis, Haramaya University.

ZWANE, E.M., 2016. Perceptions of extension advisors on privatisation and outsourcing as an option for development paradigm in Limpopo province and the lessons for future. South Africa. S. Afr. J. Agric. Ext., 44(2):71-83. 
